Ровенець Т. О., к.е.н., доцент (Національний університет водного господарства та природокористування, м. Рівне)

\title{
ІДЕНТИФІКАЦІЯ ПОНЯТТЯ «СОЦІАЛЬНІ ВИТРАТИ»: РЕТРОСПЕКТИВНИЙ ВИМІР
}

\section{У статті проведено ретроспективний аналіз ідентифікації поняття «соціальні витрати», на основі якого визначено сучасний підхід до його розуміння.}

Ключові слова: соціальні витрати, вартість робочої сили, витрати на відтворення робочої сили, оплата праці, заробітна плата, соціальні виплати.

Нині все більш гостро постає питання дотримання суб'єктами господарювання принципів соціально відповідальної діяльності, що безпосередньо пов'язано з виникненням такого поняття, як «соціальні витрати», та, відповіно, необхідністю їх класифікації, обліку, аналізу і визначення впливу на економічні показники діяльності. Це обумовлює актуальність дослідження економічної сутності соціальних витрат.

Окремі теоретичні, методичні та практичні аспекти обліку і аналізу соціальних витрат знайшли відображення у працях відомих вітчизняних та зарубіжних вчених А.В. Базилюк, В.Ф. Бесєдіна, М.Т. Білухи, Ф.Ф. Бутинця, С.Ф. Голова, О.А. Грішнової, Д. Добії, Р. Ентоні, Н. Калдора, Р. Каплана, Дж. Кендріка, Т.М. Кір'ян, А.М. Колота, Ф. Котлера, С.Я. Король, Е.М. Лібанової, Є.В. Мниха, Л.В. Нападовської, Д. Нортона, А.В. Озеран, М.С. Пушкаря, Н.М. Реутової, В.А. Савченко, В.В. Сопка, К. Томаса, Дж. Р. Хікса, В.О. Шевчука.

Разом з тим питання еволюції поняття «соціальні витрати» досліджено недостатньо.

Метою даної публікації $є$ розкриття економічної сутності соціальних витрат в ретроспективі та уточнення сучасного тлумачення даного поняття.

Основними завданням публікації є:

- критично проаналізувати тлумачення сутності поняття «соціальні витрати» в історичному аспекті;

- визначити сучасний підхід до розуміння соціальних витрат на основі проведеного ретроспективного аналізу. 
Соціальні витрати, як окрема категорія, вимагають чіткого визначення змісту та класифікації, як основи організації їх фінансового, податкового, управлінського обліку.

Аналіз наукового доробку вітчизняних і зарубіжних вчених свідчить, що поняття «соціальні витрати» досліджувалося представниками різних наукових шкіл та напрямів, також дане поняття зустрічається в багатьох галузях науки і має різні тлумачення.

У працях видатних вчених-економістів, представників класичної політичної економії, які досліджували робочу силу як товар, вартість робочої сили (А. Смітт, Д. Рікардо, У. Петті, Ж.Б. Сей) розглядається як категорія суспільно необхідних витрат на відтворення робочої сили, яка певною мірою $є$ підґрунтям формування соціальних видатків держави та соціальних витрат підприємства. У. Петті намагався визначити «природну ціну праці». Ії розмір він визначав вартістю засобів існування працівника. У. Петті стверджував, що заробітна плата повинна зводитися до вартості мінімальних засобів існування для того, щоб постійно змушувати працівників працювати [1, С. 229]. А. Смітт у «Дослідженні про природу і причини багатства народів» дає аналіз витрат праці на виробництво - це витрати на харчування, житло, відпочинок та ін. Ціну праці він визначає на основі розміру ії оплати. Заробітна плата для працівника набуває форми доходу, а для капіталіста $€$ витратами, які спрямовуються на підтримання робочої сили. Підприємці прагнуть знизити витрати на робочу силу, що породжує конфлікт інтересів продавців і покупців робочої сили, і таким чином формує ціну праці, тобто доходи працівника. А. Смітт розглядав заробітну плату як винагороду за працю і визначав нормальний рівень заробітної плати вартістю засобів існування працівника та його сім"ї. Він також вважав, що висока заробітна плата сприяє зростанню продуктивності праці [2, С. 25]. На відміну від А. Смітта, Д. Рікардо виокремлював «природну» та «ринкову» ціну праці, а заробітну плату розглядав як прибуток працівника від участі в процесі виробництва. «Природна ціна праці», на думку науковця, - вартість засобів існування працівника і його сім"ї, а «ринкова ціна праці» - заробітна плата, яка залежить від попиту і пропозиції робочої сили [3, C. 88].

Варто звернути увагу на концепцію Ж.Б. Сея, який, не відкидаючи ідею трудового походження вартості, був переконаний, що вартість створюється не лише працею. В процесі виробництва, окрім праці, беруть участь капітал і земля, які взаємопов'язані і кожен 3 яких створює свою частину вартості, яка перетворюється у відповідний доход, що використовується на зарплату, прибуток, ренту [4, С. 11]. 
Згідно 3 «теорією утримання», розробленою представником класичної політичної економії Н.В. Сеніором, саме пожертва праці та капіталу дають право робітникам та підприємцям на отримання відповідної винагороди: заробітної плати і прибутку. Аналіз взаємозв'язку заробітної плати і прибутку дозволив вченому зробити висновок, що основою нарощування виробництва $є$ прибуток, який заощаджується і перетворюється в інвестиції. Відтак величину заробітної плати він ставив в залежність від утримання підприємця, а не робітника. Водночас динаміку заробітної плати вчений пов'язував зі змінами товарних цін [5, С. 98]. Згідно з «теорією фонду заробітної плати», розробниками якої $€$ представники класичної політичної економії Д.Р. Мак-Куллох, Дж. Мілль, розмір заробітної плати робітників залежить від фіксованого фонду, який формується підприємцем за рахунок авансової частки капіталу, призначеного для оплати праці. Боротьба робітників за підвищення заробітної плати є марною, оскільки при фіксованому фонді оплати праці доходи робітників можуть зростати лише за рахунок скорочення кількості зайнятих. Відтак єдиним джерелом зростання оплати праці робітників є нарощування обсягів капіталу та прибутків як джерела збільшення фонду заробітної плати [5, С. 100].

Засновник марксистської економічної теорії К. Маркс вважав, що мінімальна межа суспільно необхідних витрат на відтворення робочої сили в певних суспільних умовах - це вартість життєвих засобів, що фізично необхідні робітникові (витрати на утримання сім'ї робітника, витрати на освіту робітника, витрати на задоволення матеріальних і духовних потреб) [1, С. 250]. Свої твердження Маркс будував на основі застосування категорії «вартості робочої сили», вартість якої роботодавець сплачує і яка $€$ меншою від вартості праці працівника. Тобто, він прирівнював зарплату до витрат на відтворення робочої сили, а решта вартості робочої сили - додаткова вартість, яка підлягає розподілу між капіталістами і землевласниками. Додаткова вартість - це залишковий прибуток, в розмірі якого зацікавлений капіталіст. Останній також зацікавлений у зменшенні рівня зарплати. Суттєвим недоліком марксизму, на нашу думку, було те, що єдиною мірою вартості розглядалася праця, а інші фактори (наприклад, капітал) не враховувалися. Також, характеризуючи робочу силу як специфічний вид товару, марксисти ототожнювали працівника лише з фактором виробництва, відкидаючи його здатність мислити, розвиватись, співчувати і т. ін. [1, С. 189].

Дещо іншим є підхід Ф. Бастіа, який на відміну від К. Маркса вважав, що працівник і капіталіст мають єдину спільну мету - ство- 
рення продукту для подальшого розподілу. Теорія заробітної плати Ф. Бастіа заснована на твердженні, що заробітна плата і прибуток збільшуються зі зростанням капіталу, проте темп зростання заробітної плати вищий [4, С. 26].

Таким чином, спільною рисою класичної школи політичної економії і марксистів $€$ те, що вони розглядали оплату праці в контексті вартості і ціни робочої сили, яка безпосередньо залежить від суспільно необхідного робочого часу на виробництво тієї суми засобів життя, що необхідна для існування працівника та його родини, а також залежить від граничної корисності натурального обсягу та структури життєвих засобів.

Представники австрійської школи граничної корисності, зокрема Е. Бем-Баверк, вважали, що створена працівником нова вартість повинна бути більшою, ніж його заробітна плата, оскільки частина знову створеної вартості повинна стати винагородою підприємцю за «утримання» від витрати капіталу на свої особисті потреби [6, С. 192].

Економісти неокласичного напряму заперечували проти росту заробітної плати, вважаючи їі основною причиною безробіття, що, на нашу думку, $\epsilon$ неефективним стосовно мотивації підвищення продуктивності персоналу. Тому дана теорія не була поширена на практиці. Початківець неокласичного аналізу А. Маршалл розглядає теорію граничної продуктивності праці як джерело вартості продуктивності факторів виробництва. На його думку, граничний продукт визначає рівень доходів за вкладення кожного фактора у виробництво. Відповідно, «справедлива» оплата прирівнюється до продуктивності останнього додаткового працівника, якого може найняти капіталіст за умови, що всі інші фактори залишаються незмінними [4, С. 158]. Важливим доробком А. Маршалла було те, що він відділив проблему вартості від проблеми ціноутворення праці, що не змогли пояснити класики та маржиналісти.

Представник неокласичної школи політичної економії А. Пігу розглядав соціальні витрати як витрати всього суспільства на забезпечення добробуту. Згідно з його «економічною теорією добробуту», поняття індивідуального добробуту не зводиться до його економічного аспекту і включає такі показники якості життя, як умови довкілля, умови праці та відпочинку, доступність освіти, громадський порядок, медичне обслуговування [4, С. 110]. М.І. Туган-Барановський розробив соціальну теорію, яка узгоджувала інтереси робітників і підприємців, розкривала їх спільне джерело доходів [1, С. 26].

Згідно з теорією маржиналізму, метою людської діяльності $\epsilon$ максимальне задоволення потреб, яке досягається шляхом отримання доходів у вигляді компенсації за роботу, яка може бути не ли- 
ше у вигляді заробітної плати, а й у вигляді різного роду заохочень, премій за різноманітні досягнення та інших соціальних виплат (і не лише матеріальних) [1, С. 435].

На підставі теорії загальної рівноваги Я. Певзнера та С. Брагінського (розробленої в основному А. Маршаллом та Л. Вальрасом), представників інституціоналізму в Україні, за умов рівноваги попиту та пропозиції вартість усіх факторів (у т.ч. робочої сили) відповідає їх граничній продуктивності, тобто внеску у виробництво продукту (вартості). Саме ця вартість і виплачується робітникові - продавцю послуг праці. Більш конкретно ця величина визначається не тим, як оцінює підприємець потреби робітника для підтримання його життє- і працездатності, а результатами праці, тобто плідністю праці кожного власника робочої сили зокрема. Позитивним у такому підході $є$ спроба оцінити вартість товару з погляду не лише суспільних витрат виробництва, а й корисності. Намагаючись обґрунтувати більшу доцільність застосування категорії «вартість послуг праці», Я. Певзнер та С. Брагінський посилаються на те, що на підтримання відтворювального процесу сучасна держава змушена витрачати майже третину національного доходу. Отже, можна стверджувати, що вартість робочої сили не знаходить адекватного виміру лише з огляду на його граничну корисність, що вирішальну роль тут відіграє підхід як до вартості суспільно необхідних витрат для відтворення робочої сили нормальної якості. Щоб постійно відтворювати таку робочу силу, суспільство, яке неспроможне зробити це в межах корпоративної власності, в особі держави витрачає значну частину національного доходу на соціальні цілі [5, С. 120].

Соціальні витрати держави, яка проводить активну соціальну політику - це видатки державного бюджету на здійснення соціального захисту населення. Ідеї створення соціально спрямованої держави як ключового економічного інституту найбільш яскраво проявляються у поглядах представників інститутціоналізму: Т. Веблена, У. Гамільтона, А. Гобсона. Найпрогресивнішими ідеями прихильників інституціоналізму є необхідність участі працівників у власності та управлінні виробництвом, надання їм соціальних гарантій [5, С. 128], що, на нашу думку, є потужним мотиваційним інструментом та оптимальним до застосування у сучасних умовах на противагу збільшенню заробітної плати.

Представник нової інституціональної теорії Р. Коуз у своїй статті «Проблема соціальних витрат» розглядає соціальні витрати як суму приватних витрат і екстерналій (зовнішніх ефектів, побічних наслідків будь-якої діяльності, що стосуються не безпосередніх їі учасни- 
ків, а третіх осіб). Р. Коуз вважав, що існування екстерналій призводить до розходження між приватними і соціальними витратами. У випадку негативних ефектів приватні витрати виявляються нижчими від соціальних, при позитивних зовнішніх ефектах - соціальні витрати нижчі від приватних. Причиною негативних наслідків від зовнішніх ефектів вчений називає недосконале законодавство [6, С. 330].

За Дж. Кендріком, соціальні витрати - це всі витрати, що необхідні для фізичного формування, розвитку і забезпечення стабільного рівня життя людини, а саме витрати на підтримання здоров'я, здобуття загальної і спеціальної освіти, витрати на пенсійне забезпечення [7, С. 74].

К. Макконел, С. Брю розглядали соціальні витрати як витрати на людський капітал. В той же час вони поділяли ці витрати на 3 види: витрати на освіту, включаючи підготовку за місцем роботи; витрати на охорону здоров'я, що складаються з витрат на профілактику захворювань, медичне обслуговування, дієтичне харчування, покращення житлових умов та витрати на переміщення робочої сили [8, С. 150].

Згідно 3 теорією «ланцюга цінностей», запропонованою М. Портером, соціальні витрати розмежовуються як витрати основної (первинної) діяльності, яка бере участь у створенні доданої вартості та витрати допоміжної (вторинної) діяльності, яка бере участь у споживанні новоствореної вартості. До соціальних витрат основної діяльності М. Портер відносить оплату праці та інші виплати працівникам, що не включаються у фонд оплати праці; соціальне страхування та соціальне забезпечення; організація й обслуговування робочих місць, охорона праці; підготовка і перепідготовка працівників. Соціальними витратами допоміжної діяльності $є$ витрати діяльності, спрямованої на покращення соціально-психологічного клімату в колективі (організація свят, ювілеїв); витрати благодійницької і спонсорської діяльності; витрати на організацію і функціонування соціальної інфраструктури підприємства [7, С. 73]. Вітчизняні вчені, зокрема В. Сопко та В. Пархоменко, до соціальних витрат відносять відрахування на соціальне страхування та витрати, які зовсім не пов'язані з виробництвом, тобто витрати на створення й утримання соціальної інфраструктури підприємства [7, С. 74].

У теорії управління персоналом соціальні витрати розглядаються як компенсаційний пакет - система винагород, яка використовується підприємством і включає в себе основну заробітну плату (базову зарплату), додаткову оплату (заохочувальні виплати, премії, бонуси) та соціальні виплати або пільги (бенефіти) (соціальний пакет): медичне обслуговування, страхування, безкоштовне харчування, на- 
вчання за рахунок підприємства, надання туристичних путівок, відпочинок за рахунок підприємства, оплата проїзду в громадському транспорті, надання позик, залучення коштів працівників під \%, оплата житла, цінні подарунки, додаткові відпустки, дольова участь персоналу у прибутках, продаж акцій компанії та ін. [9, С. 30]. У теорії управління розвитком персоналу розглядаються витрати на розвиток персоналу за складовими групами вартості робочої сили («Пряма оплата праці», «Оплата за невідпрацьований час», «Витрати на професійне навчання» та ін.) [9, С. 82]. У міжнародних корпораціях витрати на соціальні програми (медичне обслуговування, страхування життя, пенсійне забезпечення та ін.) відіграють значну роль у стимулюванні і розвитку персоналу та розглядаються як одна із форм довгострокових інвестицій.

Аналіз наукового доробку вітчизняних і зарубіжних вчених показав, що соціальні витрати нерозривно пов'язані з поняттям «вартість робочої сили», «оплата праці», «витрати на відтворення робочої сили», «заробітна плата» та здебільшого розглядаються залежно від суб'єктів, які їх здійснюють: соціальні витрати держави і соціальні витрати підприємства.

Нині термін «соціальні витрати» використовується досить широко в офіційних джерелах, популярних і спеціальних періодичних виданнях, науковій літературі. Однак, проведений критичний аналіз підтверджує, що в кожному випадку мова стосується різних витрат. Різними ці витрати можуть бути за призначенням, за джерелами фінансування, структурою і т.д.

Сьогодні на практиці під соціальними витратами підприємства часто розуміють відрахування до фондів загальнообов'язкового пенсійного та соціального страхування. До цієї ж категорії можуть відносити витрати на оплату праці та інші виплати працівникам підприємства, що у сумі складає витрати на персонал. Загальний обсяг витрат підприємства на персонал включає: погодинну та відрядну заробітну плату, всі види преміальних виплат, вартість соціальних пільг, витрати на спецодяг, обладнання побутових та інших приміщень соціально-культурного або спортивного призначення, нарахування єдиного соціального внеску. Але такий підхід є спрощеним. Поняття «соціальні витрати»є значно ширшим. Як показує аналіз, логічно віднести до соціальних витрат витрати на реалізацію підприємством соціальних заходів, пов'язати їх із забезпеченням потреб різних соціальних груп, що входять у сферу його інтересів, у т.ч. персоналу, акціонерів, споживачів, постачальників, місцевих громад, неприбуткових організацій та інших соціальних груп, визначених кодексом соціальної від- 
повідальності бізнесу.

Отже, дослідження поглядів різних наукових шкіл, вітчизняних і зарубіжних науковців щодо тлумачення економічної сутності соціальних витрат в історичному аспекті дозволяє стверджувати, що на сьогодні не існує єдиноприйнятого визначення поняття «соціальні витрати». На нашу думку, в основі виникнення різних підходів до розуміння соціальних витрат лежить їх розгляд в наступних двох аспектах: соціальні витрати держави та соціальні витрати підприємства. Існує тісний взаємозв'язок у розподілі функцій при наданні соціальних гарантій між державою і підприємством. Однією з важливих умов посилення соціальної спрямованості реформ є досягнення узгодженості між державою і підприємством у раціональному перерозподілі зобов'язань в процесі здійснення соціальних витрат. На даному етапі переходу до ринкової економіки соціальні витрати підприємств доцільно розглядати не стільки як витрати, скільки як інвестиції, які підвищують конкурентоспроможність підприємництва. Витрати на професійну підготовку та перепідготовку персоналу, на освітні програми і проекти щодо створення високоякісного резерву робочої сили, кошти, які інвестуються в медичне обслуговування працівників та членів їхніх сімей, $є$ фактором посилення дієздатності «людського капіталу», а, відповідно, і зростання економічної ефективності діяльності суб'єктів господарювання. Соціальні витрати як держави, так і підприємства відображають їх соціальну політику.

1. Мочерний С. В. Основи економічної теорії : навч. посіб. К. : Видавничий центр «Академія», 1998. 464 с. 2. Смитт А. Исследование о природе и причинах богатства народов. М. : Прогресс, 1978. - 494 с. 3. Рикардо Д. Сочинения. Т. 1. М., 1955. 468 с. 4. Базилевич В. Д. Історія економічних учень : підручник. У 2 ч. 2-е вид., випр. К. : Знання, 2005. Ч. 1. 567 с. 5. Тейлор Ф. Принципы научного менеджмента. М. : Изд-во «Контроллинг», 1992. - 137 с. 6. Кларк Дж. Б. Распредиление богатства. М. : Соцэкгиз, 1934. 225 с. 7. Пацула О. Соціальні витрати підприємства та їхня класифікація. Вісник КНТЕУ. 2006. № 3. 8. Макконел К., Брю С. Экономикс: принципы, проблемы и політика : в 2-х томах. Пер. с англ. М. : Республика, 1992. Т. 1, 399 с. Т. 2, 400 с. 9. Савченко В. А. Управління розвитком персоналу : навч. посіб. К. : КНЕУ, 2002. $351 \mathrm{C}$.

\section{REFERENCES :}

1. Mochernyi S. V. Osnovy ekonomichnoi teorii : navch. posib. K. : Vydavnychyi tsentr «Akademiia», 1998. 464 s. 2. Smitt A. Issledovanye o pryrode y prichynakh bohatstva narodov. M. : Prohress, 1978. - 494 s. 3. Rikardo D. Sochineniia. T. 1. M., 1955. 468 s. 4. Bazylevych V. D. Istoriia ekonomichnykh 
uchen : pidruchnyk. U 2 ch. 2-e vyd., vypr. K. : Znannia, 2005. Ch. 1. 567 s. 5. Teilor F. Printsipy nauchnoho menedzhmenta. M. : Izd-vo «Kontrollinh», 1992. - 137 s. 6. Klark Dzh. B. Raspredylenye bohatstva. M. : Sotsэkhyz, 1934. 225 s. 7. Patsula 0. Sotsialni vytraty pidpryiemstva ta yikhnia klasyfikatsiia. Visnyk KNTEU. 2006. № 3. 8. Makkonel K., Briu S. Ekonomiks: printsypy, problemy i politika : v 2-kh tomakh. Per. s anhl. M. : Respublika, 1992. T. 1, 399 s. T. 2, 400 s. 9. Savchenko V. A. Upravlinnia rozvytkom personalu : navch. posib. K. : KNEU, 2002. 351 s.

Рецензент: д.е.н., доцент Осадча О. О. (НУГВП)

Rovenets T. O., Candidate of Economics (Ph. D.), Associate Professor (National University of Water and Environmental Engineering, Rivne)

\section{IDENTIFICATION OF THE CONCEPT «SOCIAL EXPENSES»: RETROSPECTIVE MEASUREMENT}

The article provides a retrospective analysis of the identification of the «social expenses» concept, on the basis of which a modern approach to its understanding is determined.

Keywords: social expenses, labor costs, labor reproduction costs, wages, wages, social benefits.

Ровенец Т. О., к.э.н., доцент (Национальный университет водного хозяйства и природопользования, г. Ровно)

\section{ИДЕНТИФИКАЦИЯ ПОНЯТИЯ «СОЦИАЛЬНЫЕ РАСХОДЫ»: РЕТРОСПЕКТИВНЫЕ ИЗМЕРЕНИЯ}

В статье проведен ретроспективный анализ идентификации понятия «социальные расходы», на основании которого определен современный подход к его пониманию.

Ключевые слова: социальные расходы, стоимость рабочей силы, затраты на воспроизводство рабочей силы, оплата труда, заработная плата, социальные выплаты. 